\title{
Sustaining Small Scale Farming: Evidence of Poverty and income Disparity among Rural Farming Households in South-South Region of Nigeria
}

\author{
Sunday B. Akpan \\ Akwa Ibom State University, Department of Agricultural Economics and Extension, Nigeria \\ Edet J. Udoh \\ University of Uyo, Department of Agricultural Economics and Extension, Nigeria \\ Inimfon V. Patrick \\ Akwa Ibom State University, Department of Agricultural Economics and Extension, Nigeria
}

\begin{abstract}
The incidence of poverty is evidenced among rural farm households in developing societies. As a result of persistence poverty among rural farm households, there is sudden upsurge in agricultural livelihood diversification and rural-urban migration resulting in high rate of urban unemployment. To help generate suitable policy variables to help tackle this rampaging issue in the South- south region of Nigeria, this study specifically analyzes poverty and income inequality as well as identified determinants of poverty among rural farm households in Akwa Ibom State, Nigeria. Data were collected from 390 rural farm household heads spread across the rural areas of the State. Combination of sampling methods was employed to sample cross sectional data from respondents. The study used descriptive tools and regression analysis (Tobit regressions) to analyze information collected. The socio-economic analysis reveals that, most farming household heads were male; an average of 12.3 years of formal was discovered; social capital formation was poor, while average age stood at 42.5 years. About $33.08 \%$ of male headed households and $22.05 \%$ of female headed households live below poverty line in the study area. Income inequality index revealed 0.4210 for male headed households and 0.4531 for female counterpart. The Tobit model estimates revealed that, household head farming experience, years in social organization, level of formal education, farm and non-farm income were negative drivers of rural poverty in the region. Household's age, household size, structure of land ownership and gender were positive drivers of poverty among rural farming households. It is recommended that sound family welfare packages should be implemented in the rural communities. Also, social capital formation should be promoted among rural farming households, while adult education policies should be re-visited. Government of the region should also improve educational facilities in the rural areas and make marginal lands available to less privileged farmers.
\end{abstract}

Keywords: rural youth; poverty; income inequality; agricultural production; Nigeria.

UDC 364.22:631

JEL Classification: I3, Q12, R2

DOI: http://dx.doi.org/10.22178/pos.14-5

\section{Introduction}

In developing countries, agriculture still remains the most prominent livelihood activity of most rural dwellers [5, 26]. The sector is known to employ more than $70 \%$ of the rural population and is a major absorber of labour during period of economic crises or recession. Literature has provided evidence that, more than $60 \%$ of the rural population who are mostly farmers in Sub
Saharan Africa live below poverty line and do not have sufficient access to social amenities and infrastructures [7, 27, 29, ]. As noted by A. Garba [15], the UN Human Poverty Index, in 1999, placed Nigeria among the 25 poorest nations in the world. To substantiate this fact, the UNDP report [28] asserted that, about 68.7 million Nigerians were poor in 2004; while it rose to 112.7 million in 2010 representing $69 \%$ of the population. Issues related to poverty and income ine- 
quality are mostly reported as a rural phenomenon and more prevalent among farming households in Nigeria [18, 23, 25]. For instance, the National Bureau of Statistics in 2010 published income inequality indices of $43.28 \%$ and $43.34 \%$ for urban and rural areas respectively; while the national Gini-coefficient Index stood at $44.70 \%$. According to B. Aigbokhan [2], income inequality affects economic growth and instigates social conflict as well as poverty.

Globally, poverty and income inequality have been identified as major limitations to economic growth and development. Despite years of commitments in agricultural researches and development through enunciation of poverty alleviation programmes and institutions with evidences of achievements; hunger, income inequality as well as poverty still triumph over majority of $\mathrm{Ni}$ gerians [12]. For instance, in 2004 the relative poverty stood at $54.4 \%$ representing 68.7 million Nigerians; whereas in 2010, poverty incidence rose to $69.00 \%$ representing 112.47 million Nigerians; while in 2011 it was $71.50 \%$ [19]. The report also revealed that, $73.2 \%$ of the rural population was poor while $61.8 \%$ of urban population lives below poverty line in 2010 . In recent survey, income inequality has also showed irregular pattern in Nigeria as revealed by NBS [19]. The Gini index was 0.434 in the South-South region and 0.444 in the South East region and averaged at 0.447 for the country. This revealed that, income is unevenly distributed among urban and rural households in the country. This implies that income inequality and poverty incidence existed at various levels among categories of individuals in the society. Persistence disparity in household income and continuous increase in societal poverty could lead to inefficient allocation of resources, militancy, revolt, criminalities and stunted growth in economic activities. In agricultural sector, the devastating situation of income inequality and increasing societal poverty is made worst by aggravated rural- urban migration among active labour force and diversification of agricultural lands [4, 9].

In response to these societal scourges, governments at various tiers in Nigeria have set up several policy frameworks to fine-tune existing rural development policies and built new ones in order to improve on the income level of rural dwellers basically farmers. For instance, in 2008, the Akwa Ibom State Government initiated integrated farming scheme for agricultural graduates and set up a micro credit scheme to assist youths engaged in the agricultural production. In 2011, a gender specific skill development scheme was enunciated to help improved the wellbeing of enterprise female youths in the state, through the provision of soft loans to beneficiaries. Despite these incentives and the expanding markets potentials for the primary and secondary agricultural commodities in the state; the poverty status of rural farmers has steadily declined in recent years as evidenced by increasing involvement of farmers in off farm income generating activities $[5,6]$. This situation has a short and long term negative effects on the welfare of farmers and could also negate the national objective of selffood sufficiency in the near future. Given the presence level of poverty and income inequality prevalence among farming population in the country; the current attempt to diversify the revenue based of the country following increasing crude oil price volatility could be jeopardize if agricultural sector is the preferred area of intervention. This is stem from the fact that, majority of farmers are poor and income is highly skewed among Nigerians.

To hasten the agricultural development process will required motivating rural farmers to become active participants in the ongoing engineering of the agricultural sector in the country. Thus investigating issues concerning rural farmers' poverty and income inequality is a necessity in this era of diversification drive in Nigeria. Hence, based on this premised, the study specifically identified factors that determine rural poverty among rural farming households and analyzes the degree of income inequality and poverty among them.

\section{Literature Review}

Several empirical studies have been carried out on poverty and income inequality among rural households in Nigeria. For instance, M. Ogbonna [21] conducted an empirical study to determine factors that influence rural poverty among yam farm households in south eastern Nigeria. The result identified level of education, social group membership, farming experience and participation in agricultural workshop as negative driver of rural poverty. However, household dependency ratio had a positive relationship with rural poverty. In the like manner, B. Asogwa [8] estimated the determinants of poverty depth among the peri-urban farmers in Benue State, Nigeria. 
Result showed that, farm total economic efficiency, household income, farm size, household size, age, education, farming experience, access to credit, gainful employment for household members, membership of farmer association, extension contact and valuable farm asset significantly influenced poverty among respondents. In the South west region of Nigeria, S. Olawuyi and M. Adetunji [24] analyzed the incidence, severity and the determinants of household poverty in Ogbomoso Agricultural Zone of Oyo State. They found that poverty rises with the increase in household size while it reduces with increase in level of education, farm size and participation in non-farm jobs as alternative sources of livelihood (livelihood diversification). According to the result, gender, household size, years spent in school, farm size and non-farm jobs were found to be important and significant factors determining poverty in the study area. Still in the same region, 0. Igbalajobi [17] analyzed the determinants of poverty among rural farmers in Ondo State. The result of the Logit model indicated that age, gender, marital status, household size, access to credit, farm income and educational level of respondents were the major determinants of poverty among rural farm households.

Researcher S. Akinbode [3] also assessed the poverty situation and its determinants among urban households in the south-west region of $\mathrm{Ni}$ geria. The FGT decomposition poverty in the area showed that 34 percent of the households were poor with a poverty gap and severity indices of 0.11 and 0.06 respectively. The study further revealed that educational level of heads, household size, gender of heads, dependency ratio and access to credit exerted significant effect on household poverty in the region. Another study in the region conducted by A. Adetayo [1] examined the poverty status of farm households in Ogun State. Poverty incidence was found to be higher among male headed (60\%) and farming (63.9\%) households and those having over five members (66.1\%). The Logit regression further indicates that the likelihood of being poor were more with large households, non-educated farm households head and households without access to credit and other non-farm income. Researchers F. Ogwumike and M. Akinnibosun [22] were concerned with the determinants of poverty among farming households in Nigeria. Their study adopted the National Bureau of Statistics (NBS) measure of poverty and employed the logit regression model to estimate the effect of the socioeconomic variables on poverty among farming households. Their results showed high incidence of poverty among farming households. Age, size of household, income, and number of farms were found to be the major determinants of poverty among farming households.

In the South-South region of Nigeria, S. Edoumiekumo, M. Tamarauntari and S. Steve [14] examined the incidence, depth and severity of poverty in Bayelsa state. Results from the logit regression showed that agriculture and household size increases the probability that a household will be poor while dwelling in the urban area; being headed by male, a naira increase in households per capita expenditure on education and per capita expenditure on health and a year's increase in the number of years spent in school by household head reduces the probability that a household will be poor. Recently, in the South West, scientists B.Awotide, T. Awoyemi and I. Oluwatayo [10] assessed income inequality and poverty among rural households in Akinyele local government area, of Oyo State. The study revealed that income was more evenly distributed among the female headed households than the male counterparts in the study area. Empirical result revealed that, number of dependent ratio and households' size significantly increases the probability of falling below the poverty line among the respondents. The result further showed that, access to credit and contact with extension agents had significant poverty reducing effects. In the Northern region of Nigeria, K. Duniya and G. Rekwot [13] investigated the determinants of poverty among groundnut farming households in Jigawa State. Result showed that, age of household head, marital status of household head, education, and membership of cooperative had negative relationship with poverty incidence while farming experience and extension contact had positive significant relationship.

From the pool of literature in Nigeria, it is evidenced that, not much information on poverty and income inequality of rural farm households existed in the South-South region. The region needs empirical evidence to generate reliable policy framework for sustainable rural household poverty reduction strategy. Hence, this study was designed to fill this research gap in the literature. 


\section{Research Methodology}

The Study Area. The study was conducted in Akwa Ibom State, located in the Southern region of Nigeria. It is located between latitudes $4^{\circ} 321$ and $5^{\circ} 331$ North and longitudes $7^{\circ} 251$ and $8^{\circ} 251$ east. It has a total land area of areas of $7,246 \mathrm{~km} 2$. The mean annual temperature of the state lies between $26^{\circ} \mathrm{C}$ and $29^{\circ} \mathrm{C}$ and average sunshine of about 1,450 hours per year. The mean annual rainfall ranges from $2,000 \mathrm{~mm}$ to $3,000 \mathrm{~mm}$, depending on the area. Naturally, maximum humidity is recorded in July while the minimum occurs in January. The state is bordered on the East by Cross River State, on the West by Rivers State and Abia State, and on the South by the Atlantic Ocean. Akwa Ibom State has a population of about $3,902,051$ and a population density of 634 persons per square kilometres [20]. The state is basically an agrarian society where crops like maize, okra, waterleaf, cassava, yam and rice are cultivated in large quantities. Fishery including aquaculture; livestock and poultry businesses thrives well in the State. The state was picked among other states in the region because of it rich agricultural potentials. In addition, the state has well demarcated rural and urban areas. Furthermore, the geography of the state supports diverse agricultural activities, in addition to has been one of the most peaceful States in region and Nigeria.

Sample Size Selection. Following the work of Cochran (1963), a representative sample size from a large population of farmers in the study area was obtained using the equation (1) specified below:

$$
S_{n}=\frac{z^{2} \rho(1-\rho)}{D^{2}}
$$

where $S_{n}$ - the required sample size;

$z$ - the standard normal variety (at $95 \%$ confidence interval, type 1 error; 1.96 );

$p$ - the expected proportion of farmers in the population (we assumed that $60 \%$ of the population are farmers from 1995 farm survey in the State)

$d$ - the absolute error or precision at $5 \%$ type 1 error.

The sample size is derived as shown in equation (2).

$$
S_{n}=\frac{(1.96)^{2} 0.60(1-0.60)}{(0.05)^{2}}=369 .
$$

However, the study adopted proportional sampling method in the study area, hence a total of 390 (three hundred and ninety respondents) were used in the study.

Data Source and Sampling Procedures. Primary data were used and respondents were rural farming household heads (including crop and animal farmers and aquaculture). Combination of sampling methods was used to select respondents. Firstly, two local government areas with clearly distinct rural areas were purposively selected from the three Senatorial districts in the State. A total of six (6) local government areas were selected and used for data collection. In the second stage, five rural villages were randomly sampled from each of the six local government areas selected. A total of thirty rural villages were randomly sampled from the six local government areas used for data collection. In the third stage, thirteen (13) farmers were randomly picked from each of the sampled village. Hence, a total of three hundred and ninety (390) farmers were randomly sampled and used for data collection.

Empirical Model. The Foster-Greer-Thorbecke (FGT) model was used to analyze poverty status of the rural farming households. The FGT poverty index is generally expressed as thus (3):

$$
P_{\alpha}=\frac{1}{n} \sum_{i=1}^{q}\left(\frac{Z-Y_{i}}{Z}\right)^{\alpha}
$$

where $n$ - total number of households in population; $q$ - the number of poor households;

$Z$ - the poverty line for the household;

$Y_{i}$ - per capita household income for $i$ th farmer;

$\alpha$ - poverty aversion parameter and takes on value 0 , 1 and 2;

$\left(\frac{Z-Y_{i}}{Z}\right)$ - proportion shortfall in income below the poverty line.

Decomposition of poverty index. Following Foster-Greer-Thorbecke (FGT) model, household poverty can be decomposed into the following sub-units:

a) When $\alpha=0$, then FGT index is expressed as:

$$
P_{0}=\frac{1}{n} \sum_{i=1}^{q}\left(\frac{Z-Y_{i}}{Z}\right)^{\alpha}=\frac{1}{n} \sum_{i=1}^{q}\left(\frac{Z-Y_{i}}{Z}\right)^{0}=\frac{q}{n} .
$$


This is called the Incidence of poverty or headcount index, which measures the proportion of farmers that is poor or falls below the poverty line. This gives the head count ratio or the incidence of poverty which is the percentage of respondents that are poor or whose per capita household income is below the poverty line.

b) When $\alpha=1$, then FGT index is expressed as:

$$
P_{1}=\frac{1}{n} \sum_{i=1}^{q}\left(\frac{Z-Y_{i}}{Z}\right)^{\alpha}=\frac{1}{n} \sum_{i=1}^{q}\left(\frac{Z-Y_{i}}{Z}\right)^{1}
$$

This is called Poverty depth or Poverty gap index, which measures the extent to which individuals fall below the poverty line as a proportion of the poverty line. It reflects both incidence and depth of poverty or the proportion of the poverty line that the average poor will require to attain to the poverty line.

c) When $\alpha=2$, then FGT index is expressed as:

$$
P_{2}=\frac{1}{n} \sum_{i=1}^{q}\left(\frac{Z-Y_{i}}{Z}\right)^{\alpha}=\frac{1}{n} \sum_{i=1}^{q}\left(\frac{Z-Y_{i}}{Z}\right)^{2}
$$

This is called Poverty severity index which measures the squares of the poverty gaps relative to the poverty line. The index measures the severity of poverty which is the mean of square proportion of the poverty gap. When multiplied by 100 , it gives the percentage by which a poor household's per capita income should increase to push them out of poverty.

Measurement of Poverty Line. This was done to separate farming households into poor and nonpoor groups. As a benchmark, two-third of the mean per-capita income was used as a threshold. Households whose mean per-capita income fall below the poverty line are regarded as being poor while those with their per-capita income is on or above the benchmark are non-poor.

Household Per Capita Income $($ HPCI $)=\frac{\text { Household income }}{\text { Household Size (HHS) }}$

Total Household per capita Income (THPCI) $=\sum H P C I$

Mean Total per capita income $(M T H P C I)=T H P C I / n$

Then Poverty Line $(P L)=\left(\frac{2}{3}\right)($ MTHPCI $)$
Determinants of poverty among Rural Farming Households in Akwa Ibom State. To determine factors that influence poverty among rural households in Akwa Ibom, a Tobit regression model was specified. Implicitly, the specified model is shown in equation as follows (7)-(8):

$$
\begin{aligned}
& \in\left(Y_{i}^{*} / X_{i}\right)=X_{i} \beta, \\
& Y_{i}^{*}=X_{i} \beta+\varepsilon_{i},
\end{aligned}
$$

where $i=1,2,3, \ldots, \mathrm{n}$.

$Y^{*}$ - a latent response variable that is observed for values greater than a non-stochastic constant $\left(K_{1}\right)$ define as poverty line and censor otherwise;

$X_{i}$ - an observed $1 \times k$ vector of explanatory variables;

$\varepsilon_{i} \sim$ i. i.d. $N\left(0, \sigma^{2}\right)$ and is independent of $X_{i}$.

The observed $Y_{i}$ is defined by the following measurement equation (9):

$$
Y_{i}=\left\{\begin{array}{rl}
Y^{*} & \text { if } Y^{*}<\mathrm{K} \\
0 & \text { if } Y^{*}>\mathrm{K}
\end{array},\right.
$$

The implicit form of Tobit model can further be expressed as thus (10):

$$
Y_{i}=\left\{\begin{array}{c}
Y_{i}=X_{i} \beta+V_{i} \text { if } Y_{i}^{*}<Қ \text { where } V_{i} \sim \text { i.i.d. } N\left(0, \delta^{2}\right) \\
0=X_{i} \beta+V_{i} \text { if } Y_{i}^{*}>\text { Where } V_{i} \sim \text { i.i.d. } N\left(0, \delta^{2}\right)
\end{array},\right.
$$

$Y_{i}$ is the dependent variable. $Y_{i}$ is observed and a continuous variable when a rural household per capita income is below than the poverty line income (Қ), it is not observed otherwise. $Y_{i}^{*}$ is the rural household per capita income. $X_{i}$ is a vector of explanatory variables, $\beta$ is a vector of unknown coefficient or parameter and $V_{i}$ is an independently distributed error term. The marginal effect on the latent dependent variable $Y^{*}$ is expressed as follows (11):

$$
\frac{\delta Y^{*}}{\delta X_{i}}=\frac{\delta E\left|Y^{*}\right|}{\delta X_{i}}=\beta_{i},
$$


Explicitly, the Tobit model used in this study is expressed as thus (12):

$$
\begin{aligned}
& P O V=\vartheta_{0}+\vartheta_{1} A G E+\vartheta_{2} G E N+\vartheta_{3} E D U+ \\
& +\vartheta_{4} M A R+\vartheta_{5} S O C+\vartheta_{6} I C T+\vartheta_{7} L A O+ \\
& +\vartheta_{8} N F I+\vartheta_{9} H H S+\vartheta_{10} E X P+\vartheta_{11} F A I+ \\
& +\vartheta \beta_{12} D E P+\vartheta_{13} E X T+U_{i}
\end{aligned}
$$

where POV - Poverty incidence in a respondent household as defined in equation (10);

$A G E$ - Age of farming household head (years);

GEN - Gender of farming household head (1 - male household head, and 0 for female household head);

$H H S$ - Household size (number);

$E D U$ - Formal education of household head (years);

$S O C$ - Membership in a social organization (years);

$L A O$ - Land ownership structure $(1$ for inheritance and 0 otherwise);

EXT - Household head's access to extension agent in the last farming season (dummy, 1 for yes and 0 for no);

$M A R$ - Marital status of respondent (dummy 1 for married and 0 otherwise);

DEP - Dependent ratio (number of Children less ears plus adult greater than 65 year the household size);

$N F I$ - Non -farm income of respondents (Naira);

FAI - Farm income of farming household head (Naira);

ICT - household head access to ICT facilities (dummy, 1 for yes and 0 for No);

$U=$ stochastic error term.

\section{Measurement of Income Inequality among Farming Households in the study area. The} study used Gini coefficient to measure income inequality among farming households in the study area. It is defined as a ratio with values range from 0 to 1 . The numerator is the area between the Lorenz curve of the distribution and the uniform distribution line; the denominator is the area under the uniform distribution line. The Gini index is the Gini coefficient expressed as a percentage. Gini coefficient of 0 corresponds to perfect income equality (i.e. everyone has the same income) and 1 corresponds to perfect income inequality (i.e. one person has all the income, while everyone else has zero income). As proposed by Brown, the coefficient is expressed as thus (13):

$$
G=\left|1-\sum_{k=1}^{n}\left(X_{k}-X_{k-1}\right)\left(Y_{k}+Y_{K-1}\right)\right|
$$

where $G$ = Gini coefficient;

$X_{k}=$ Cumulated proportion of population variable;

$Y_{k}=$ Cumulated proportion of income variable.

Verification of Multicollinearity among Explanatory Variables used in the Analysis. Multicollinearity is among the commonest econometric problems of the cross sectional data analysis. This property of econometric was verified among explanatory variables to ensure the econometric stability and reliability of the regression estimates. The Variance Inflating Factor (VIF) was estimated and used to verify the presence of the multicollinearity among the explanatory variables. For VIF, the minimum possible value is 1.0; while value greater than 10 indicates a probably collinearity between the specified explanatory variable in question and the rest of the predictors in the model. According to [16], VIF is estimated using the formula stated below (14):

$$
V I F_{j}=\left\{1 / 1-R_{j}^{2}\right\},
$$

where $R_{j}^{2}$ represents the multiple correlation coefficient between one of the explanatory variable (designated as dependent variable) and the other specified explanatory variables in the study.

The explicit model explaining the above mechanism is shown in equation (15).

$X_{j}=\varphi_{0}+\varphi_{1} X_{1}+\varphi_{2} X_{2}+\cdots+\varphi_{n} X_{n}+\varepsilon_{n}$.

\section{Result and Discussion}

The Socio-economic Characteristic of Respondents. The descriptive statistics of farmers in the study area is shown in Table 1 . The result revealed an average age of about 42.5 years for the farming population in the study area. This means that, most farmers in the area are fast aging out from active farming age. This result calls for an urgent move by government of the region and all stake holders to mobilize younger ones into farming businesses in the area. Farmers' average period of formal education stood at 12.30 years. This result connotes that, most farmers in the area are educated, and there is high possibility of 
agricultural innovation adoption among them. About $62.30 \%$ of the sampled farmers were male farmers. The result also showed that, $89.50 \%$ of farmers sampled were married. Social capital formation among farmers was low in the study area, as shown by an average of about 2 years in social organizations. It was also discov- ered that, a farmer browse the internet at least of 2.6 times a month. The result further showed that, about $66.70 \%$ of farmers owned farm land either by inheritance or purchase. The rest acquired farm lands through lease and borrowed arrangement among others.

Table 1 - Descriptive Statistics and socio-economic of rural farming household heads in Southern Nigeria (Both poor and Non-poor respondents)

\begin{tabular}{|l|r|r|r|r|r|}
\hline \multicolumn{1}{|c|}{ Variable } & \multicolumn{1}{c|}{ Mean } & \multicolumn{1}{c|}{ Minimum } & Maximum & \multicolumn{1}{c|}{ Std. Dev. } & \multicolumn{1}{c|}{ C.V. } \\
\hline POV & 3903.04 & 0.00000 & 17142.9 & 5381.02 & 1.379 \\
\hline AGE & 42.449 & 21.000 & 65.000 & 8.046 & 0.189 \\
\hline HHS & 5.759 & 1.000 & 16.000 & 2.508 & 0.436 \\
\hline DEP & 0.485 & 0.000 & 2.000 & 0.385 & 0.794 \\
\hline EXP & 13.877 & 0.000 & 45.000 & 8.529 & 0.615 \\
\hline SOC & 2.267 & 0.000 & 25.000 & 4.424 & 1.952 \\
\hline LAO & 0.667 & 0.000 & 1.000 & 0.472 & 0.708 \\
\hline FAI & 97010 & 0.000 & 500000. & 117459. & 1.211 \\
\hline ICT & 2.574 & 0.000 & 80.000 & 10.304 & 4.003 \\
\hline NFI & 33160 & 0.000 & 1.680000 & 97951.0 & 2.954 \\
\hline EXT & 0.821 & 0.000 & 1.000 & 0.384 & 0.468 \\
\hline GEN & 0.623 & 0.000 & 1.000 & 0.485 & 0.779 \\
\hline MAR & 0.895 & 0.000 & 1.000 & 0.307 & 0.343 \\
\hline EDU & 12.295 & 0.000 & 15.000 & 3.454 & 0.281 \\
\hline
\end{tabular}

Source: Computed by authors, 2015. Note monetary value is expressed in Naira. Variables are as defined previously.

An average farm income stood at N97010 in the study area; whereas the non-farm income was N33160. Farmers have moderate family size with a mean household size of 6 members; while extension agent visit average at 8 times per season. The farming experience among respondents averaged at about 14 years in the study area.

Test result to verify collinearity among specified explanatory variables used. Table 2 presents the Variance Inflating Factor (VIF) test and tolerance factor test results used to verify the status of multicollinearity of explanatory variables used in the Tobit regression model.

The result reveals that there was no serious or significant collinearity among explanatory variables in the specified Tobit model. For instance, the estimated VIF with respect to each variable was greater than unity, but less than the threshold value of 10 . The tolerance factor was also less than unity validating the VIF results.
Table 2 - The Variance Inflation factors (VIF) test result

\begin{tabular}{|l|c|c|}
\hline Variables & VIF estimates & Tolerance Factor \\
\hline AGE & 1.543 & 0.6809 \\
\hline HHS & 1.326 & 0.7541 \\
\hline DEP & 1.113 & 0.8985 \\
\hline EXP & 1.410 & 0.7092 \\
\hline SOC & 1.251 & 0.7994 \\
\hline LAO & 1.135 & 0.8811 \\
\hline FAI & 1.164 & 0.8591 \\
\hline ICT & 1.069 & 0.9355 \\
\hline NFI & 1.033 & 0.9681 \\
\hline EXT & 1.084 & 0.9225 \\
\hline GEN & 1.077 & 0.9285 \\
\hline MAR & 1.050 & 0.9524 \\
\hline EDU & 1.058 & 0.9452 \\
\hline
\end{tabular}

Source: Computed by authors using gretl software.

The result suggests that, the explanatory variables specified do not cluster together or exhibited multi-collinearity tendencies. 
This implies that the estimates of the Tobit model to an appreciable extent are consistent, best, and unbiased. In other words, the estimates of the Tobit model are stable over time.

\section{Poverty Status and Income inequality among} rural Farmers in Akwa Ibom State. Poverty levels among sampled farmers in the State were analyzed using the three indicators of poverty as highlighted in the Foster, Greer and Thorbecke (FGT) model. The indicators were: the incidence of poverty, poverty depth and severity of poverty. Result in Table 3 revealed that, the index of prevalence or incidence of poverty among male and female farming population was 0.3308 and 0.2205 respectively.

Table 3: Poverty and income inequality Parameters of Rural farming Households in Akwa Ibom State

\begin{tabular}{|l|r|r|r|}
\hline \multicolumn{1}{|c|}{ Indicators } & \multicolumn{1}{c|}{ Male } & Female & \multicolumn{1}{c|}{ Total } \\
\hline $\begin{array}{l}\text { Incidence of } \\
\text { poverty }\end{array}$ & 0.3308 & 0.2205 & 0.5513 \\
\hline Poverty depth & 0.1873 & 0.1377 & 0.3250 \\
\hline $\begin{array}{l}\text { Poverty } \\
\text { severity index }\end{array}$ & 0.1406 & 0.1064 & 0.2470 \\
\hline $\begin{array}{l}\text { Poverty line } \\
\text { income }\end{array}$ & 17248.37 & 17248.37 & 17248.37 \\
\hline $\begin{array}{l}\text { Population } \\
\text { Mean per } \\
\text { capita income }\end{array}$ & 25872.56 & 25872.56 & 25872.56 \\
\hline $\begin{array}{l}\text { Total } \\
\text { respondents }\end{array}$ & 129 & 86 & 215 \\
\hline $\begin{array}{l}\text { Farming } \\
\text { households } \\
\text { under poverty } \\
\text { line }\end{array}$ & 114 & 61 & 175 \\
\hline $\begin{array}{l}\text { Farming } \\
\text { household } \\
\text { above poverty } \\
\text { line }\end{array}$ & & & \\
\hline Gini Coeficient & 0.4210 & 0.4531 & 0.7801 \\
\hline $\begin{array}{l}\text { Gini Coefficient } \\
\text { index (\%) }\end{array}$ & 42.10 & 45.31 & 78.01 \\
\hline $\begin{array}{l}\text { Mean per } \\
\text { capita income } \\
\text { of poor }\end{array}$ & 7479.45 & 6480.66 & 7079.934 \\
\hline
\end{tabular}

Source: Computed by authors, 2016. Note monetary value is expressed in Naira.

This means that about $33.08 \%$ of male farmers and $22.05 \%$ of e female farmers in the region are deep in poverty or have their per capita income less than the poverty line income. The result shows that, in the rural areas male farmers are more vulnerable to poverty than their female counterparts in the State. The finding corresponded to the report [1] in Ogun State. It is suggested that, the culture and the societal value prevailed in the study area could be the principal contributor to this result. The overall index of poverty index was 0.5513 , this shows that about $55.13 \%$ of rural farmers' population in the study area is poor or have per capita income below the poverty line income. This means that majority of rural farming households in the region live in poverty. This scenario is a threat to future farming sustainability in the region. An urgent policy aim at increasing farm income of rural farmers is strongly advocated. This will help to curtail rural - urban migration and agricultural diversification as well as reduce the menace of poverty among rural farmers in the region.

The result also revealed the poverty depths of 0.1873 for male respondents and 0.1377 for female farmers in the study area. The result implies that, about $18.73 \%$ and $13.77 \%$ of per capita income is needed to bring poor male and female farmers respectively from below poverty line up to the poverty line income. This means that, poverty incidence is more among male farmers compared to female farmers in Akwa Ibom State. The overall population poverty depth index stood at 0.3250 , implying that, about $32.50 \%$ of per capita income is required to push poor rural poor farmers from below poverty up to the threshold poverty line income in the study area.

The severity of poverty index was 0.1406 for male headed households and 0.1064 for female headed households in the study area. This result means that, male farmers need about $14.06 \%$ increases in per capita income to push them away from severe poverty. Likewise, the female farmers need about $10.64 \%$ increment in per capita income to escape from severe poverty. An average severe poverty index of 0.2470 was discovered for the population. This means that, about $24.70 \%$ of per capita income is required to push rural farmers' population trap by severe poverty to the poverty line. This finding is in consonance with research report [3] in south-west region of Nigeria.

The estimated poverty indices based on the socioeconomic characteristics of rural farming households is presented in Table 4. The result shows that the prevalence of poverty was higher 
among households with fewer members $(37.69 \%)$ than those with much more members (17.44\%).

Table 4: Poverty Indices based on the Socioeconomic Qualities of rural farming households in Akwa Ibom State

\begin{tabular}{|c|c|c|c|}
\hline $\begin{array}{l}\text { Socio-economic } \\
\text { Characteristics }\end{array}$ & $\begin{array}{l}\text { Prevalence } \\
\text { of Poverty }\end{array}$ & $\begin{array}{l}\text { Poverty } \\
\text { Depth }\end{array}$ & $\begin{array}{l}\text { Severity } \\
\text { of } \\
\text { Poverty }\end{array}$ \\
\hline \multicolumn{4}{|l|}{$\begin{array}{l}\text { Household Size } \\
\text { (Members) }\end{array}$} \\
\hline $1-6$ & 0.3769 & 0.2348 & 0.1880 \\
\hline $7-16$ & 0.1744 & 0.0902 & 0.0590 \\
\hline \multicolumn{4}{|l|}{$\begin{array}{l}\text { Age Distribution } \\
\text { (Years) }\end{array}$} \\
\hline $21-35$ & 0.1308 & 0.0725 & 0.0559 \\
\hline $36-50$ & 0.3615 & 0.2210 & 0.1711 \\
\hline $51-65$ & 0.0589 & 0.0314 & 0.0200 \\
\hline \multicolumn{4}{|l|}{$\begin{array}{l}\text { Education } \\
\text { (Years) }\end{array}$} \\
\hline $0-12$ & 0.3103 & 0.1799 & 0.1360 \\
\hline 13-15 & 0.2410 & 0.1452 & 0.1110 \\
\hline \multicolumn{4}{|l|}{$\begin{array}{l}\text { Membership in } \\
\text { Social Group } \\
\text { (years) }\end{array}$} \\
\hline $0-10$ & 0.5410 & 0.3183 & 0.2426 \\
\hline $11-25$ & 0.0103 & 0.0067 & 0.0044 \\
\hline \multicolumn{4}{|l|}{$\begin{array}{l}\text { Farming } \\
\text { Experience } \\
\text { (Years) }\end{array}$} \\
\hline $0-20$ & 0.4718 & 0.2722 & 0.2030 \\
\hline $21-45$ & 0.0795 & 0.0528 & 0.0440 \\
\hline \multicolumn{4}{|l|}{$\begin{array}{l}\text { Access to } \\
\text { Extension } \\
\text { Services } \\
\text { (dummy) }\end{array}$} \\
\hline Yes & 0.4487 & 0.2675 & 0.2065 \\
\hline No & 0.1026 & 0.0575 & 0.0405 \\
\hline $\begin{array}{l}\text { Land Ownership } \\
\text { structure }\end{array}$ & & & \\
\hline Inheritance & 0.3641 & 0.1941 & 0.1399 \\
\hline Others & 0.1872 & 0.1309 & 0.1071 \\
\hline
\end{tabular}

Source: Computed by authors, 2016. Note monetary value is expressed in Naira

This result implies that, households with many members will likely have many alternative sources of income and extensive family labour for farming activities. In a rural setting, increase family labour will lower farm recurrent expenditure and probably increases the household per capita income.
Also, poverty incidence existed more among household heads whose ages range from 36 to 50 years $(36.15 \%)$ than those of 21 to 35 years $(13.08 \%)$ and 51 to 65 years (5.89\%). The reasoning behind this result follows that; age range of 21 to 35 years are youthful and may not be saddle with much household responsibilities; while the age range of 51 to 65 years are aged and are mostly catered for by the younger members of the society.

A lot of economic incentives like remittances, pension, alms and rent from landed properties among others are available for this group of farming household heads. On the other hand, age group of 36 to 50 years represents a very active age range. Mostly they are saddled with heavy household responsibilities and have much interest on farm investments, and hence lower household per capita income.

It is also observed that, respondents with higher number of years of formal education $(24.10 \%)$ are less poor compared with those with fewer years $(31.03 \%)$. The reason could be the exposure and degree of technology adoption which is positively correlated with increase in years of formal education. Similar results are reported for membership in a social organization and farming experience of household heads. Those farming household heads with fewer numbers of years in a social organization and farming are poorer than those with many years of farming experience and membership in a social organization. Long membership in a social organization promotes social capital formation and sharpens farming experience as well as income generating capacity of members.

Furthermore, respondents that have access to agricultural extension services (44.87\%) were poorer than those without contact $(10.26 \%)$. This result pinpointed to the quality of information transfer and the efficiency in extension service delivery in the state. This is a clarion call for improve service delivery by the extension service system in the state. The prevalence of poverty was higher among respondents that inherited their farmland than those that acquired otherwise. Land fragmentation has contributed to this result. It is also expected that farmers that acquired farm land apart from inheritance are business conscious or commercial oriented farmers. Hence, they will likely consider farming as a business rather than a mere occupation. 
Gini Coefficient of rural farming households in Akwa Ibom State. The estimated Gini coefficient showed that income inequality existed among male and female rural farming households in the region. The result showed that income inequality is more conspicuous among female farmers than the male farmers. A Gini coefficient index of $45.31 \%$ for female farmers is higher than $42.10 \%$ for the male farmers in the region. This implies that, farm income is more evenly distributed among the male respondents than the female counterparts.

Determinants of Poverty among rural farming households in Akwa Ibom State. Tobit model estimates used to identify determinants of poverty among rural farming households in Akwa Ibom State is shown in Table 5.

Table 5: Estimates of Tobit Model (Determinants of Poverty among rural farm households in Akwa Ibom State)

\begin{tabular}{|c|c|c|c|c|}
\hline Variable & Coefficient & Standard Error & Z-value & P-values \\
\hline Constant & -8051.33 & 3099.44 & $-2.5977^{* * *}$ & 0.0094 \\
\hline $\mathrm{AGE}$ & 149.442 & 56.1536 & $2.6613^{* * *}$ & 0.0078 \\
\hline HHS & 1445.41 & 162.776 & $8.8798^{* * *}$ & $<0.0001$ \\
\hline DEP & 439.739 & 1158.15 & 0.3797 & 0.7042 \\
\hline EXP & -147.273 & 58.1271 & $-2.5336^{* *}$ & 0.0113 \\
\hline SOC & -357.114 & 88.6434 & $-4.0287^{* * *}$ & $<0.0001$ \\
\hline LAO & 3956.92 & 957.016 & $4.1346^{* * *}$ & $<0.0001$ \\
\hline FAI & -0.0818876 & 0.006490 & $-12.6175^{* * *}$ & $<0.0001$ \\
\hline ICT & -27.3812 & 37.1789 & -0.7365 & 0.4614 \\
\hline NFI & -0.0347875 & 0.01142 & $-3.0470^{* * *}$ & 0.0023 \\
\hline$\overline{\text { EXT }}$ & -178.332 & 1014.59 & -0.1758 & 0.8605 \\
\hline GEN & 1808.46 & 865.566 & $2.0893^{* *}$ & 0.0367 \\
\hline MAR & 380.163 & 1235.52 & 0.3077 & 0.7583 \\
\hline EDU & -7.59299 & 2.29646 & $-3.3064^{* * *}$ & 0.0011 \\
\hline Log Likelihood & -2260.46 & & Chi-square (13) & $222.85^{* * *}$ \\
\hline Normality test (2) & $29.39^{* * *}$ & & Hannan-Quinn & 4574.50 \\
\hline Akaike Criterion & 4550.91 & & Schwarz Criterion & 4610.41 \\
\hline
\end{tabular}

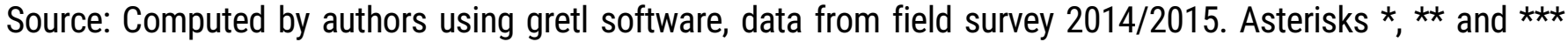
represent significant levels at $10 \%, 5 \%$ and $1 \%$ respectively. Variables are as defined in equation 5 .

The diagnostic statistics of the estimated model revealed that, the Chi-square (13) of 222.85 is significant at $1 \%$ probability level. This indicates that the specified Tobit model has a strong explanatory power, hence goodness of fit. It also confirmed that the estimated Pseudo $R^{2}$ is statistically significant. This means that, important variables that influenced occurrence of poverty among rural farming households were included in the specified Tobit model.

The empirical result revealed that, age of household head has a significant positive relationship with occurrence of poverty among rural farming household in Akwa Ibom State. This implies that, as farmer's age advances, the tendency of being poor increases too. In the analysis of poverty we discovered the age range of 36 to 50 years as a critical period where poverty becomes so prominent among farming household heads in the study area. The result indicates that, a unit increase in age of a poor farming household head will lead to a reduction in its household per capita income by approximately N150 from the poverty line or alternatively increases poverty incidence. This finding could be as a result of enormous family responsibilities often accompanied a typical rural African family. The issue of culture and extended family system in most rural communities in the study area could be partly responsible for this result. Similar finding have been reported in other region of Nigeria by [8, $13,17,22]$.

The coefficient of the household size in the model is positive and statistically significant at $1 \%$ probability level. This means that, increase in 
household size will increase prevalence of poverty among poor farming households in the study area. The result satisfies the priori expectation; because increase in household size is directly related to increase in household's expenditure. Increase in household size also portrays increase in non-farm budgetary allocation and perhaps reduction in farm investment and income generating capacity. This means that, increase in household size is also associated with increase in family responsibility and reduction in per capita household income. This invariably means that farmers with high household size will likely have per capita income deep below the poverty line income. For instance, the result revealed that, one unit increase in the household size will increase poverty incidence by reducing poor household's per capita income by N1445.41. The result corroborates with the research findings of $[1,3,8,10,13,14,17,21,22,24]$.

The result also showed a positive significant relationship between structure of land ownership and prevalence of poverty among farming households in the study area. This means that, increase in the number of inherited farm land increases the prevalence of poverty among farming households in Akwa Ibom State. The size of the marginal effect shows that, the structure of land ownership is the most important determinants of poverty among farming households in the study area. For instance, one unit increase in the number of inherited farmland among farming households increases poverty incidence by reducing their per capita income by N3956.92. In a typical rural setting in the southern region of $\mathrm{Ni}$ geria, genuine and commercially oriented farmers have difficulty in acquiring land due to increasing land fragmentation, tenure system, urbanization and high population density as well as other cultural barriers in the zone. The result suggests that, most poor farming households in the study area operate on fragmented inherited farm lands which do not encourage commercialized farming or considerable farm investment for higher income generation. This finding calls for an urgent need to revisit most of the land ownership policies in Akwa Ibom State. There is also need to develop marginal lands and encourage cooperative farming in the region. Reseachers B. Asogwa, J. Umeh and V. Okwoche [8] have reported similar finding.

The slope coefficient of gender (i.e. male household heads among sampled respondents) is posi- tively correlated with poverty among farming households in the study area. This means that, poverty increases more among male household heads compared to the female counterparts. The result revealed that, a number increase in the male household head among farming households' increases poverty incidence by reducing households' per capita income by an average of N1808.46. This result could be due to the cultural believed in the study domain which delegated more responsibilities to the male folks and the issue of extended family system. The result agrees with the findings of S. Olawuyi and M. Adetunji [24], O. Igbalajobi, A. Fatuase and I. Ajibefun [17] and S. Akinbode [3] in Nigeria.

On the other hand, the relationship between poverty incidence and farming experience of farming household head is negative and statistically significant. This connotes that, as farming experience increases, it will dwindle the prevalence of poverty among poor farming household heads. For instance, a unit increase in farming experience of poor farming household heads in the study area will decrease poverty incidence by appreciating their per capita household income by N147.27. This result satisfies priori expectation because increase in farming experience will increase the probability of adopting better technology and best farm management practices which will eventually increase farm household income. Researchers like $[8,13,21]$ obtained similar result in other regions of the country.

The coefficient of farmers' membership in social organization also exhibited a strong negative correlation with prevalence of poverty among farmers in Akwa Ibom State. This means that, increase in years of membership in social societies reduces incidence of poverty by increasing per capita household income by N357.11. This result suggests that, social capital helped in poverty reduction among rural farmers in the region. Social capital formation is essential in sharing ideas, information and technology among farmers. Social networking among farmers is capable of stimulating market for agricultural goods thereby enhancing farm income. Also, it is a forum for sharing benefits of technology and experiences which help to improved farm income. The finding is in line with the report $[8,13,21]$ in Nigeria.

Similarly, farmers' farm income and non-farm income have negative association with poverty prevalence among farmers in the region. Alterna- 
tively, increase in farmers' farm and non-farm income reduce poverty incidence among them. Empirically, the result shows that, a unit increase in farm and non-farm income significantly reduce the incidence of poverty by increasing farmers' household per capita income marginally by N0.08 and N0.04 respectively. The finding shows that, these variables should be considered as among important variables in tackling poverty among farmers in the State. The size of the marginal effect suggests that rural farmers in the study area are willing to stay in agricultural production. The magnitude of coefficient of the nonfarm income also suggests that, agricultural diversification tendencies among rural poor farmers are low while farming is the major livelihood activities among them. Researchers like [17, 22, $24]$ have discovered similar result in other region of the country.

The marginal effect years of formal education has negative relationship with incidence of poverty among youth farmers in the study area. A unit increase in formal education reduces poverty incidence by increasing the household per capita income of farmers by N7.59. The result indicates that, increase in years of education reduces the incidence of poverty among rural farmers in the State. The result satisfies the priori expectation as increase in formal education will likely increase the exposure, interaction and economic opportunities of rural farmers. With increase in education, rural farmers can access loanable fund, ICT facilities and explore various routes for accessing other farm incentives. Increase in education is often linked to increase in capital formation and adoption of risky farm exercise. The finding agrees with other empirical findings such as $[3,8,17,21,24]$.

\section{Conclusion, Summary and Recommendations}

The study analyzed the poverty status, determinants of poverty and income inequality among rural farmers in Akwa Ibom State, Nigeria. The welfare of rural farmers is paramount in sustaining agricultural production in the region. Analyzing the poverty status of rural farmers is one way of identifying suitable policy variables needed by policy makers to form and implement sound policy framework for rural farm development. The study showed that, there is significant prevalence of poverty and income inequality among male and female farming household heads in Akwa
Ibom State. It is revealed that, about $33.03 \%$ and $22.05 \%$ of male and female farmers respectively languished in poverty in the study domain. The estimated Gini coefficients indicate that, female headed farming households have higher index of income inequality compared to the male counterpart. The empirical result revealed that, household head's years in social organization, level of formal education, amount of non-farm and farm incomes as well as farming experience are negative drivers of poverty among rural farming households in Akwa Ibom State. On the other hand, household head age, household size, nature of land ownership and male gender of household head positively correlated with poverty incidence in the study area.

Based on findings of the research, the following recommendations were proposed:

1. A sound family welfare package should be design and implemented in the rural communities to check excessive family expenditure by farmers.

2. Empowering and strengthening of farmers' groups/social capital formation in the rural communities will help to reduce poverty and income inequality among rural farmers.

3. The agricultural extension system in the State should be strengthened to impact positively on rural famers' income.

4. Marginal farm land should be developed and farm lands re-distributed to both male and female farming household heads in the State.

5. A strong policy on family planning targeted on rural households should be enunciated and implemented to curtail excessive family expenditure among rural farmers in the state.

6. It is suggested that, adult education policies should be re-visited; while government of the region should make concerted effort to improve educational facilities in the rural areas of the state.

\section{Acknowledgement}

The authors appreciate the contribution of Akwa Ibom State Agricultural Development Programme (AKADEP) Staff for helping the research team fill questionnaires used in this study. We also extend our sincere gratitude to our families for their supports. 


\section{References}

1. Adetayo, A. (2014). Analysis of farm households poverty status in Ogun states, Nigeria. Asian Economic and Financial Review, Vol. 4, 3, 325-340. Retrieved from http://www.aessweb.com/pdffiles/aefr\%204(3),\%20325-340.pdf

2. Aigbokhan, B. (2000). Poverty, Growth and Inequality in Nigeria: A Case Study. Retrieved from http://unpan1.un.org/intradoc/groups/public/documents/IDEP/UNPAN003895.pdf

3. Akinbode, S. (2013). Profiles and Determinants of Poverty among Urban Households in South-West Nigeria. American Journal of Economics, 3(6), 322-329. Retrieved from http://article.sapub.org/10.5923.j.economics.20130306.11.html

4. Akpan, S. (2010). Encouraging Youth Involvement in Agricultural Production and Processing in Nigeria. Retrieved from https://goo.gl/bHzsFO

5. Akpan, S., \& E. Udoh (2016). Farmers' Decision to Participate in Government Agricultural Programmes in a Volatile Political Environment: A Case study of Famers in the South-South region of Nigeria. Russian Journal of Agriculture and Socio-Economic Sciences, 5(53), 135-148. doi: 10.18551/rjoas.2016-05.18

6. Akpan, S., Inimfon, V., Samuel, U., \& Damian, I. (2015). Determinants of decision and participation of rural youth in agricultural production: a case study of youth in southern region of Nigeria. Russian Journal of Agriculture and Socio-Economic Sciences, 7(43), 35-48. doi: 10.18551/rjoas.201507.05

7. Apata, T., Apata, O., Igbalajobi, O., \& Awoniyi, M. (2010). Determinants of rural poverty $\quad$ in $\quad$ Nigeria: evidence from small holder farmers in south-western, Nigeria. Journal of Science and Technology Education Research, Vol. 1(4), 85-91. Retrieved from http://www.academicjournals.org/article/article1379498480_Apata\%20et\%20al\%202.pdf

8. Asogwa, B., Umeh, J., \& Okwoche V. (2012). Estimating the Determinants of Poverty Depth among the Peri-Urban Farmers in Nigeria. Current Research Journal of Social Sciences, 4(3), 201-206. Retrieved from http://maxwellsci.com/print/crjss/v4-201-206.pdf

9. Aworemi, J. Abdula-Azeez, I. Opoola, N. (2011). An appraisal of the factors influencing rural-urban migration in some selected Local Government Areas of Lagos State. Journal of Sustainable Development, 3, 136-141. doi: 10.5539/jsd.v4n3p136

10. Awotide, B., Awoyemi, T., \& Oluwatayo, I. (2012). Gender Analysis of Income Inequality and Poverty among Rural Households in Nigeria: Evidence from Akinyele Local Government Area, Oyo State. New York Science Journal, 5(10). 13-19. Retrieved from http://www.iiste.org/Journals/index.php/JBAH/article/download/20183/20658

11. Cochran, W. (1963). Sampling Techniques (2nd ed.). New York, USA: John Wiley and Sons, Inc.

12. Damisa, M., Sanni, S., Abdoulaye, T., Kamara, A., \& Ayanwale, A. (2011). Household typology based analysis of livelihood strategies and poverty status in the Sudan Savannah of Nigeria: Baseline conditions. Learning Publics Journal of Agriculture and Environmental Studies, 2(1), 146-160. Retrieved from https://goo.gl/HCtv4Z

13. Duniya, K., \& Rekwot, G. (2015). Determinants of Poverty among Groundnut Farming Households in Jigawa State, Nigeria. Asian Journal of Agricultural Extension, Economics \& Sociology, 4(3), 224230. doi: 10.9734/AJAEES/2015/13539

14. Edoumiekumo, S., Tamarauntari M., \& Steve S. (2014). Income Poverty in Nigeria: Incidence, Gap, Severity and Correlates. American Journal of Humanities and Social Sciences, Vol. 2, 1, 1-9. doi: $10.11634 / 232907811402499$

15. Garba, A. (2006, July). Alleviating Poverty in Northern Nigeria. Annual Convention of Zumunta Association, Minneapolis, USA.

16. Gujarat, N., \& Dawn, C. (2009). Basic Econometric (5th ed.). New York, USA: McGraw-Hill Irwin Singapore.

17. Igbalajobi, O., Fatuase, A., \& Ajibefun, I. (2013). Determinants of Poverty Incidence among Rural Farmers in Ondo State, Nigeria. American Journal of Rural Development, 1(5), 131-137. doi: 10.12691/ajrd-1-5-5

18. National Bureau of Statistics (2006). Population Census. Retrieved from http://www.nigerianstat.gov.ng/report/103 
19. National Bureau of Statistics (2016). Publications 2006 and 2010. Retrieved June 23, 2016, from http://www.nigerianstat.gov.ng

20. National Population Commission (2006). Publications. Retrieved June 23, 2016, from http://www.qtsnigeria.com

21. Ogbonna, M., Onyenweaku, C., \& Nwaru, J. (2012). Determinants of rural poverty in Africa: the case of yam farm households in South-Eastern Nigeria. INT'L JOURNAL OF AGRIC. AND RURAL DEV, 15(2), 1129-1137. Retrieved from https://goo.gl/9YUpkv

22. Ogwumike, F., \& Akinnibosun, M. (2013). Determinants of Poverty among Farming Households in Nigeria. Mediterranean Journal of Social Sciences, 4(2) 365-373. doi: 10.5901/mjss.2013.v4n2p365

23. Okunmadewa, F., Olaniyan, S., Yusuf, A., Bankole, O., Oyeranti, B., ... Omonona, T. (2010). Poverty and Inequality among Rural Households in Nigeria. In O. Ogwumike (Ed.), Poverty and Inequality in Nigeria. Ibadan, Nigeria: Spectrum Books Ltd.

24. Olawuyi, S., \& Adetunji, M. (2013). Assessment of Rural Households Poverty in Nigeria: Evidence from Ogbomoso Agricultural Zone of Oyo State, Nigeria. Journal of Scientific Research and Reports, Vol. 2, 1, 35-45. doi: 10.9734/JSRR/2013/2196

25. Omonona, B. (2001). The determinants of poverty among farming households in Kogi State, Nigeria (Unpublished PhD Thesis). University of Ibadan, Ibadan, Nigeria.

26. Oni, L. (2014). An Assessment of Agriculture and Poverty Reduction Nexus in Nigeria. Journal of African Macroeconomic Review, Vol. 4, 1, 265-284. Retrieved from http://www.journalsbank.com/jamr_4_3.pdf

27. Poulton, C., Dorward, A., \& Kydd, J. (2005). The Future of Small Farms: New Directions for Services, Institutions and Intermediation. World Development, Vol. 38, 10, 1413-1428. doi: 10.1016/j.worlddev.2009.06.009

28. UNDP (2010). Human Development Report Nigeria 2008-2009. Achieving Growth with Equity. Retrieved from http://hdr.undp.org/sites/default/files/nhdr_nigeria_2008-2009.pdf

29. World Bank (2007). World development report 2008: Agriculture for development. Washington, D. C., USA: The World Bank. doi: 10.1596/978-0-8213-7233-3

(C) S. Akpan, E. Udoh, I. Patrick

Received 2016-09-24 


\title{
Поддержка мелких фермерских хозяйств: доказательство бедности и неравенства доходов среди сельских фермерских хозяйств южных регионов Нигерии
}

\author{
Sunday B. Akpan \\ Akwa Ibom State University, Department of Agricultural Economics and Extension, Нигерия \\ Edet J. Udoh \\ University of Uyo, Department of Agricultural Economics and Extension, Нигерия \\ Inimfon V. Patrick \\ Akwa Ibom State University, Department of Agricultural Economics and Extension, Нигерия
}

\begin{abstract}
Аннотация. Случаи бедности наблюдаются среди сельских фермерских хозяйств в развивающихся странах. В результате сохраняющегося состояния бедности среди сельских фермерских хозяйств отмечается внезапный всплеск диверсификации средств существования и миграция из сельских районов в города, что приводит к высокому уровню безработицы в городах. Для того, чтобы помочь создать подходящие мобильные решения для содействия решению этой проблемы, актуальной для Юго-южном регионе Нигерии, в рамках настоящего исследования выполнен анализ бедности и неравенства в доходах. Были также выявлены детерминанты бедности среди сельских фермерских хозяйств в Akwa lbom State, Нигерия. Данные были получены от 390 глав сельских фермерских хозяйств, размещенных в сельской местности штата. При формировании выборки были использованы перекрестные данные. В исследовании использованы описательный метод и метод регрессионного анализа (тобит регрессий) для анализа собранной информации. Социально-экономический анализ показывает, что руководителями большинства фермерских хозяйств были лица мужского пола; стаж руководства - 12,3 лет; формирование социального капитала было недостаточным, несмотря на то, что средний возраст составил 42.5 года. Около 33,08 \% семей, возглавляемых мужчинами и 22,05 \% семей, возглавляемых женщинами, живут ниже черты бедности в исследуемой области. Индекс неравенства доходов составил 0.4210 для фермерских хозяйств с мужчиной во главе и 0.4531 для аналогичных хозяйств, возглавляемых женщинами. Оценки Тобит модели показали, что опыт главы сельского хозяйства, опыт работы в общественной организации, уровень формального образования, доходов фермы и доходов в несельскохозяйственном секторе являются отрицательные факторами, содействующими сельской бедности в регионе. Возраст фермерского хозяйства, размер хозяйства, структура собственности на землю и пол главы хозяйства были положительными факторами бедности среди сельских фермерских хозяйств. Рекомендуется, применение пакетов социального обеспечения семьи в сельских общинах. Кроме того, следует поощрять формирование социального капитала среди сельских фермерских хозяйств, при условии, что политика образования для взрослых должна быть пересмотрена. Правительству региона следует также улучшить образовательные учреждения в сельской местности и сделать marginal земли доступными для менее привилегированных фермеров.
\end{abstract}

Keywords: сельская молодежь; бедность; неравенство доходов; сельскохозяйственное производство; Нигерия.

УдК 364.22:631

JEL Classification: 13, Q12, R2

D0l: http://dx.doi.org/10.22178/pos.14-5 